\title{
Shakespeare anthologized: Taking a fresh look at Douai Manuscript MS787
}

\section{Line Cottegnies}

\section{(QpenEdition \\ 1 Journals}

\section{Electronic version}

URL: http://journals.openedition.org/shakespeare/4289

DOI: $10.4000 /$ shakespeare.4289

ISSN: 2271-6424

Publisher

Société Française Shakespeare

\section{Electronic reference}

Line Cottegnies, «Shakespeare anthologized: Taking a fresh look at Douai Manuscript MS787 », Actes des congrès de la Société française Shakespeare [Online], 37 | 2019, Online since 03 January 2019, connection on 30 April 2019. URL : http://journals.openedition.org/shakespeare/4289; DOI : 10.4000/ shakespeare.4289

This text was automatically generated on 30 April 2019.

(c) SFS 


\title{
Shakespeare anthologized: Taking a fresh look at Douai Manuscript MS787
}

\author{
Line Cottegnies
}

1 The Bibliothèque municipale of Douai possesses a transcript of nine plays dated 1694-1695, six by Shakespeare and three by Restoration playwrights, which constitutes a rare early instance of a manuscript dramatic miscellany. ${ }^{1}$ This essay aims at studying the collection as an early anthology and its logic, to interrogate the reception of Shakespeare at the end of the seventeenth century in a milieu of English recusants in exile. The manuscript is in a neat, single hand, with a few (probably eighteenth-century) annotations. ${ }^{2}$ It contains three comedies (Twelfth Night, As You Like It and The Comedy of Errors) and three tragedies by Shakespeare (Romeo and Juliet, Julius Caesar and Macbeth), bound with three Restoration plays - Nathaniel Lee's Mithridates (1678), Dryden's The Indian Emperor (1670) and Davenant's The Siege of Rhodes, Part II (1663). Dated 1694-1695, the manuscript was owned by, and presumably produced within, one of the (Catholic) English colleges or convents in Douai. Although a francophone city, Douai, which was part of the Spanish Flanders until 1667, became one of the most important educational centres for English Catholics abroad in the seventeenth and eighteenth centuries. ${ }^{3}$ The English College itself was founded in 1568 by William Allen as part of Douai university, to teach secular students and train Catholic priests. Although it was the largest, this was by no means the only English college in Douai: in fact four colleges housed British boys, all loosely affiliated to the university - the Scottish (Jesuit) College (founded 1604), the Irish College (founded 1603), a school run by the Benedictine monks of St Gregory's Priory (founded 1607), and St Bonaventure's College run by English Franciscans (or English Recollets, founded 1618). All were expropriated at the French revolution and their possessions sequestered (here in 1794), as was the case for all religious institutions in France. As we now know, English colleges and seminaries abroad, including Jesuit colleges, had a rich theatrical culture. ${ }^{4}$ Recent research around the Saint-Omer Folio has shown that Shakespeare was read or perhaps even performed in an academic context. ${ }^{5}$ The Douai manuscript points again to an early Catholic interest in Shakespeare in a college environment. The Douay College 
Diaries, which cover 150 years of life at the English College, reveal that public performances, sometimes open to the city, as well as "private" ones, were held there, in the refectory or in one of the halls - sometimes in the neighbouring Jesuit Collège d'Anchin, which had a purpose-built hall for these kinds of events. ${ }^{6}$ Most of the recorded school performances, however, are of Latin, hagiographic plays, usually about the early years of the Church: they are tragedies, sometimes followed by an unspecified "comedy" (which served as an interlude), most generally a farcical entertainment that could be in English, or include some English. This is consistent with two manuscript plays still held at the Douai library: one is a Biblical tragedy in Latin performed around 1639 in one of the English Jesuit Colleges, entitled Crispu, the other a multilingual farce, Oswinus, performed by boys at the Jesuit College of Douai in June 1697, mostly in Latin but interspersed with cues in English and French. ${ }^{7}$ But there is evidence that points to the fact that fully-fledged plays in English, not just interludes, were also performed in English colleges in the seventeenth century, and, increasingly so in the eighteenth century, in spite of official regulations such as those set in the Jesuit Ratio Studiorum (first published in 1599) ${ }^{8}$ which seem to have served as a model also in non-Jesuit colleges. ${ }^{9}$ Although there are no official records of plays performed in public (or private) in English either at Douai, or Saint-Omer, in the seventeenth century, the English College in Rome, for instance, still holds several manuscript plays in English; it is likely therefore that English plays were also occasionally performed in Douai. ${ }^{10}$ The provenance of the Douai manuscript once more draws attention to a milieu of Catholic readers of Shakespeare and to possible uses of his plays in an academic environment.

2 G. Blakemore Evans was the first scholar to note the importance of the manuscript for the field of Shakespeare studies in $1962 .{ }^{11}$ He established that the scribe used the second Folio as copy-text for the six Shakespeare plays,,$^{12}$ and pointed out that the transcript contained multiple hitherto-unrecorded readings, which in some instances predate some of the best-known emendations by eighteenth-century scholars from Rowe to Malone. In light of his previous work on printed promptbooks, he suggested that the manuscript should also be seen as a promptbook with performance in mind. It is a rare document: promptbooks, understood in the loose sense that Shattuck has given the term as "dramatic texts" (which can reflect various stages of preparation, and are not just prompters' books), are usually annotated printed texts. The Folger Library possesses over 1,000 such promptbooks, and most are printed - manuscript promptbooks often did not survive. ${ }^{13}$ The Douai MS is unique, because it is a seemingly organized collection. It thus represents a local, manuscript appropriation of printed texts, tailored to the needs (and tastes) of an "editor-reviser" whose milieu is here identified as a Catholic community of exiles. ${ }^{14}$ In many textual studies of Shakespeare, the existence of the manuscript is acknowledged. In the recent Oxford Handbook of Shakespeare, for instance, Marotti and Estill lucidly argue:

The changes made to the Douai manuscript suggest an English scribe concerned with Roman Catholic values, audience reception, and the realities of staging a play. These plays in manuscript shed light on theatricals in schools, Shakespeare on the continent and amateur performance of Shakespeare's plays. ${ }^{15}$

But if it has now become somewhat of a cliché to refer to Evans's 1962 seminal work uncritically, Ann-Mari Hedbäck's important, complementary, and partially corrective 1979 study is less often read, ${ }^{16}$ however, and few scholars go back to the evidence itself, perhaps for lack of an available edition. 
3 The manuscript is used as a textual "source" in only a handful of the most recent editions, such as the Arden 3 editions of As You Like It (edited by Juliet Dusinberre), Twelfth Night (edited by Keir Elam) and Comedy of Errors (edited by Kent Cartwright), while it is only mentioned in passing in René Weis's 2012 Romeo and Juliet - in spite of Evans's 1982 edition of the latter play which had pointed out the importance of the manuscript. ${ }^{17}$ Meanwhile, it is ignored in the recent Arden 3 Macbeth and Julius Caesar, but referenced in Marvin Spevack's 2004 edition of the latter for New Cambridge. There seems to be a small cognitive discrepancy here: the manuscript's importance is routinely recognised as a matter of course in general textual studies, which tend to take up Evans's conclusions; ${ }^{18}$ yet because it is seen merely as a promptbook created at the end of the seventeenth century within a Catholic milieu, it is also still often considered as anecdotal. As a consequence it has not quite yet been recognized as a canonical philological source (pace Dusinberre, Elam, and Cartwright). It is timely therefore, to finally make the manuscript available to the community as a whole for everyone to decide.

4 For this essay argues that the Douai MS is not just a promptbook. The term might be reductive because it implies a restricted, local or partial appropriation of the text. I would like to suggest that the manuscript also qualifies as an early edition, predating Nicholas Rowe's ground-breaking 1709 edition - which is often credited as the first modern edition of Shakespeare to follow clear textual principles. For although the Douai manuscript is based on printed texts, it shows a remarkable freedom of interpretation of the copy-text and reflects various strategies of adaptation which in many instances echo contemporary Restoration editorial standards. As shown by Don-John Dugas, it was common to perform and then publish "altered" editions of Shakespeare in the Restoration: according to him, between 1664 and 1705, out of 225 recorded performances in London, 61\% were of adaptations of Shakespeare; ${ }^{19}$ and out of the 55 editions of single plays published during the same period, $78 \%$ were adaptations. ${ }^{20}$ This might help us historicize the editorial strategy of the Douai editor. Whoever he was, it seems clear that he had an eye for the dramatic, adding for instance a dramatis personae for each Shakespeare play - for four of the plays this was the first time - while his editing is characterized by a combination of editorial flair and recklessness. This was shown by Dusinberre for As You Like It (although she seems to doubt that F2 is the copy-text ${ }^{21}$ ), by Elam about Twelfth Night, and by Hedbäck about the Davenant play. But, while these editors have followed in G. Blakemore Evans's footsteps, the remaining six plays in the volume have not been submitted to the same scrutiny. This essay aims at studying this dramatic collection as an anthology with its own rationale, to see what this might tell us about the reception of Shakespeare in this particular context, and about this particular editor-reviser's conception of editing. This implies studying the nature of the textual transformations at stake, and my examples will be drawn from the transcript of Romeo and Juliet, which has not been scrutinized since G. Blakemore Evans's study.

5 The Douai Manuscript is in fact an exceptional document. Only nine early-modern manuscript transcripts of complete plays by Shakespeare are known globally, six of which are here. What is remarkable is that it is in fact the only collection of manuscript plays, and that it also seems to be an organized one. The other extant transcripts are copies of single plays, whether they were copied as single items or severed from their original contexts is a moot point. As such the Douai volume offers an invaluable insight into its context of production, with an exceptional provenance. For, as Jeffrey Todd Knight has argued, "the involvement of collectors, curators, conservators and consumers in the 
materiality of [early-modern] texts" has often obscured the contexts of their early reception, especially, it seems to me, when Shakespeare is concerned, ${ }^{22}$ as all these agents thought fit to bind, unbind, and rebind printed or manuscript items according to their own private agendas or current trends in collecting or archiving... often separating items, in the process, which, together, could have helped us document the early reception of Shakespeare. Although of course collecting and conservation patterns are in themselves worth studying, these have often obscured the fact that early-modern "acts of storage, selection and arrangement" must be seen as "creative and productive of meaning". ${ }^{23}$ Knight concludes that recovering the early gestures of those early-modern archivists is "the challenge of a post-materialist history of reading". ${ }^{24}$ One of the valuable assets of the Douai manuscript, then, is precisely that it allows us to see one of those early "gestures" of gathering, with its own integrity and logic. As a counter-example, the Folger Library possesses an imperfect seventeenth-century transcript of Julius Caesar, with the final scene missing; and it was only in 1962 that G. Blakemore Evans (in the afore-mentioned study) was able to show that this manuscript is in fact related to the Douai transcript. He thought them both derived from a common source, perhaps itself a manuscript copied from F2, but Hedbäck convincingly showed in 1979 that the Folger manuscript is more likely to be derived from the Douai manuscript itself in a direct line. ${ }^{25}$ Because the Folger manuscript of Julius Caesar is now cut off from its context, and bound with other items, the link between the two manuscripts took years to emerge.

6 The neat symmetry of the manuscript structure (three comedies, followed by three tragedies, and then three Restoration plays, including the libretto of a semi-opera, The Siege of Rhodes), and the fact that it was written in a single hand over a relatively short period of time encourages us to think about the volume as an organized miscellany. So does the fact that it was bound quite soon after it was copied. There is no reason to doubt that the dates added after the word Finis in five out of the nine plays indicate when the transcripts were made: 13 June 1694 for Twelfth Night, 9 March 1694/5 for As You Like It, simply 1694 for Comedy of Errors and Romeo and Juliet and 1695 for Mithridates. Hedbäck tells us that when the volume was restored, in the late 1970s, it was revealed that the velum cover had been reinforced with a fragment of a printed sheet of paper from a French prayer-book dated 1697 (which is now pasted inside the cover) to be used in the parish of Saint-Vaast in Béthune (50km away from Douai). ${ }^{26}$ This tells us that the volume was bound in or after 1697, most probably towards the end of the century.

7 Of course, it would be a mistake to confuse the intentions of the scribe or the editorreviser (who might in fact be two different people) with those of the binder or, rather, the person who ordered the binding. A study of the volume's material structure confirms that the volume was bound once the different plays had been transcribed: the plays were copied independently on loose paper folded into playlets. The scribe used half-sheets folded once, making a combination of quires or half-quires of 4 sheets of 8 pages, either left loose or perhaps lightly sewn together, although no stitching points are now visible. The plays were not bound in the order in which they were transcribed, since As You Like It bears a later date than some of the plays that follow; and they are not bound in the chronological order of publication either, although the Shakespeare plays logically comes before the Restoration plays. The question of the rationale of the collection still remains: was this meant as an anthology or miscellany, or was the act of gathering purely archival? In fact we have no contemporary examples of purpose-made miscellanies of (complete) plays copied and bound together to make a new homogeneous whole, in print or 
manuscript. The first printed miscellany including a selection of plays by Shakespeare and others is probably Thomas Johnson's ten-volume set entitled A Collection of the Best English Plays, published in The Hague (and London) in 1711 and 1712 (with two additional volumes c. 1714 and 1718). The first two volumes only were dedicated to Shakespeare. ${ }^{27}$ It was very common, however, to create dramatic miscellanies by binding together singleedited quarto or octavo playbooks. This phenomenon has been well studied. ${ }^{28}$ Sir John Harington and Sir Edward Dering famously left detailed lists of their playbooks, which were bound together in volumes - Dering's collection was apparently bound in fourteen volumes. ${ }^{29}$ The Douai miscellany, although it includes discrete items copied over a couple of years by the same scribe, clearly obeys a threefold logic, generic, author-based and approximately chronological (Shakespeare before the Restoration), but whether the editor-reviser had the idea of a collection in mind from the beginning is a moot point. As a collection it presents several loose ends: although the clarity of the copy seems to point towards a collection of fair copies, there are some missing titles and erratically-placed extra blank sheets, and the presentation has not been regularized. There is no general title-page, for instance, although this could have been lost with the torn-out preliminary pages. Some intermediary titles, possibly in a different hand, characterized by an ornamental flourish, were added (presumably at a later stage), but this was not done systematically, and Romeo and Juliet does not even have a title. It seems unlikely, therefore, that the editor-reviser was involved in the supervision of the gathering and binding process. This would tend to indicate that the collection reflects more a concern for conservation, as reflected in the manuscript title written on the spine (English Comedys and Tragedys), than the logic of a Sammelband following an original plan.

But the question of the choice of these particular plays remains. They might simply reflect a personal choice, although this choice could be justified by pedagogical principles: The Comedy of Errors, Shakespeare's most Plautean comedy, would have been an obvious play to pick in a school or academic environment; and it is in fact singled out by its title here, as "The Famous Comedy of Errors Written by ye renowned poet Mr William Shakespear" (fol. 66v) - which seems to indicate that it was a favourite with this reader, although it was not on the English stage in England in the period, if we are to believe Dugas's survey. Julius Caesar would have been of interest in a school environment as offering examples of oratory and an insight into Roman history. Davenant's The Siege of Rhodes, based on the 1522 conquest of Rhodes by the Ottomans, might have appealed to the missionary zeal among the Douai community, who furnished many a martyr of the Catholic cause over two centuries. But conversely Dryden's The Indian Emperor is a play about the conquest of Mexico which sympathizes with the plight of the Inca Emperor rather than with the Spanish Catholics. Among the various settings which the plays conjure up, there is also one in particular which might have appealed to the Douai exiles for its proximity: the forest of "Ardennes" in As You Like it. Shakespeare's Arden is of course an ambiguous place, both close at hand (the forest of Arden, near Stratford) and distant (the forest of "Ardennes" which conjures up continental associations, like Petrarch's poetry). By making Duke Senior "The old Duke of Burgundy" in the dramatis personae, our editor-reviser rules out the English Arden, and settles for a locale that was in fact closer to Douai geographically: a large part of the Ardennes, like Douai itself, had been part of the Spanish Netherlands until 1667, and had historically been attached to the Duchy of Burgundy. To align the text on this choice, the editor leaves out the wrestler's line in the first scene that mentions that the Duke and his followers "live like the old Robin Hood of England" (1.1.94) (fol. 34r) - the reference to this most English of 
characters is thus left out for consistency's sake. Finally, the presence in the Douai manuscript of a Scottish play might not be accidental, given the strong Scottish presence in Douai, although Macbeth was also one of the most popular plays on the London stage in the period.

As a matter of fact, the choice of plays tends to be indicative of Restoration tastes in general. According to Dugas's survey, the three tragedies included here were among the most popular of Shakespeare's plays in the period 1660-1705. This is not the case, however, with As You Like it and Comedy of Errors (which were not). Romeo and Juliet was most often performed and read in altered versions on the Restoration stage, like Macbeth, but Julius Caesar was mostly left untouched, probably because it corresponded more to the Neoclassical taste that was then dominant. This is consistent with the degree of intervention visible in the Douai manuscript for these plays: there are few editorial changes in Julius Caesar, many more in Macbeth and Romeo and Juliet. The numerous and very thorough stage directions in the last scene of Romeo and Juliet, in particular, reveal a reader-cum-editor obviously fascinated by the pathos of the moment. The miscellany also reflects Restoration tastes in other ways: its focus on the genres of comedy and tragedy, to the exclusion of the histories and romances, reveals a Neoclassical bias, confirmed by the choice of two Restoration heroic tragedies - even though The Siege of Rhodes is more generically mixed. These Neoclassical values are also reflected by the recentering on the tragic which can be seen in Romeo and Juliet with, for instance, the excision of many comic and bawdy passages in Acts 1 and 2 - for the generic hybridity and instability of the play seems to have been an issue for the Douai editor.

These plays might also have been chosen because of their relatively manageable lengths, in contradistinction with the 3,323 words of Othello or 4,024 words of Hamlet: what is striking is the number of competent and efficient cuts made to the plays, which tend to bring down the length of each to between 1,800 words and 2,000 words - the ideal length for a performance of two hours or so. 266 lines were cut in Twelfth Night, 477 in As You Like It, only 18 in Comedy of Errors (already of short play), 174 in Julius Caesar, and 196 in Macbeth. The case of Romeo and Juliet is the most spectacular one, with 971 lines left out, which brings the total number of lines down to just over 2,000 lines. ${ }^{30}$

11 As has already become apparent, the plays are edited, rather than simply transcribed. While they do fit the general category of promptbooks as defined by Shattuck, because they are typically texts which manifest a concern for performance, they are nevertheless more than mere dramatic adaptations for specific occasions. The first kind of change concerns the addition by the editor of a dramatis personae for each play, which is in keeping with new restoration conventions: men and women are presented separately, and characters are listed in a hierarchical order. As we know, such lists are always acts of interpretation: in Romeo and Juliet, to take but one example, Prince Escalus is described as "the young Prince of Verona" - a counterintuitive move, for we tend to think of Escalus as a figure of authority. This is in fact an attempt to make sense of a line of the Folio text which the editor had no good reason to question: "You, Capulet, shall go along with me, / And, Montague, come you this afternoon, / To know our Fathers pleasure in this case". ${ }^{31}$ Most modern editors actually follow the lesson of the Quarto texts: "to know our farther pleasure". But turning Escalus into a young prince, even though his "father" is never mentioned again in the play, is an interesting dramatic choice in view of his lack of authority over his subjects - not to mention the fact that it might be one more part for a young actor. 
12 A second kind of change concerns the passages left out, which show a very astute reader at work, with a very strong dramatic sense: the cuts tend to speed up the action, and the transitions are treated with great care and with dexterity. In the case of Romeo and Juliet, the cuts reveal aesthetic, dramatic, and ideological options. The exclusion of many bawdy jokes in Acts 1 and 2 seems to indicate the editor's intolerance of the generic hybridity and of the interpenetration of comic and tragic; but conversely, other cuts concern passages in Act 1 where Romeo behaves as a conventional Petrarchan lover, loving by the book - speaking in an idiom redolent of the sonnet tradition that had obviously grown out of fashion by the end of the century. The reviser also gets rid of digressions, like the Queen Mab speech for instance (1.4), to streamline the action. As a result, the play is more narrowly focussed on the two protagonists, Romeo and Juliet - there are no cuts where they are concerned, even in otherwise very long scenes. Cuts of a more ideological nature include oaths, which are generally left out (except for a resounding "Gods bread" to express Old Capulet's anger at his disobedient daughter in 3.5.176), and several explicit references to religion, for instance to purgatory and hell, which are presented in the play as equivalent: "There is no world without Verona walles / But Purgatory, Torture, hell it selfe" (3.3.18-19). These lines are simply left out in the Douai manuscript (fol. 110v), like the reference to the distemper caused by love as the original chaos "of nothing first create" (1.1.168), another religious reference used in what could be interpreted as a frivolous context. Friar Lawrence is no longer described by Romeo as his "sin-absolver" (3.3.50), a comment which might pass as disobliging in the Catholic context and is thus excised; and a metaphorical reference to heretics burning at the stakes - obviously a sensitive metaphor in a recusant context - is left out, when Romeo compares his eyes to "transparent heretics [...] burnt for liars" (1.2.91). ${ }^{32}$

The third kind of intervention concerns the regularizing of entrances, exits and speech attributions. In the Quarto and Folio texts of Romeo and Juliet, Lady Capulet is called many different things in the speech attributions, according to her main function in the scene in relation to her interlocutors: "Lady", "Lady of the House", "Lady Capulet", "Mother", and "Wife". In the Douai manuscript, she is usually called "Lady Capulet", except in the scene when she is shown mourning for her daughter's death, where the function of the character ("Mother") still takes precedence over her other identities. The editor-reviser also adds stage directions to make the action clearer in many instances. He clarifies, for instance, the stage business in the scene where Mercutio is killed by Tybalt because of Romeo's intervention, adding: "They draw and fight Romeo steps between them" (Douai manuscript, fol. 93r). The final scene in the vault has obviously captured his imagination, and he adds numerous stage directions: Romeo "re-enters the vault", "takes the poison", "drinks", "dies"; Friar Laurence "Enter(s) with a Lanthorn, crow and spade" (a direction which comes from F2), but also "goes on and calls", "enters"; Juliet "awakes"; the Friar "exits" (as in F2), Juliet "takes Romeos dagger", "Stabs her self", and "Dyes", which expands on the more sober F2 stage direction: "Kils herselfe" (F2, fol. [ii5r]). The editorreviser thus spells out what was implicit in the dialogue. One stage direction is particularly striking. As she is on the verge of drinking the potent drug in 4.3, Juliet is seized by doubt: "Come viall - what if this mixture do not work at all? / Shall I be married then to morrow morning? / No, no, this shall forbid it. Lie thou there" (4.3: F2, Fol. ii2r). To make sense of this last line, modern editions usually follow eighteenth-century emendations, adding a stage-direction where Juliet is made to address a dagger (Rowe: "Pointing to a Dagger") or a knife (Johnson: "Lays down a knife"). The Douai manuscript 
has a unique variant, not recorded elsewhere: "lyes down a penknife" (Douai manuscript, fol. 121v) (fig. 1).

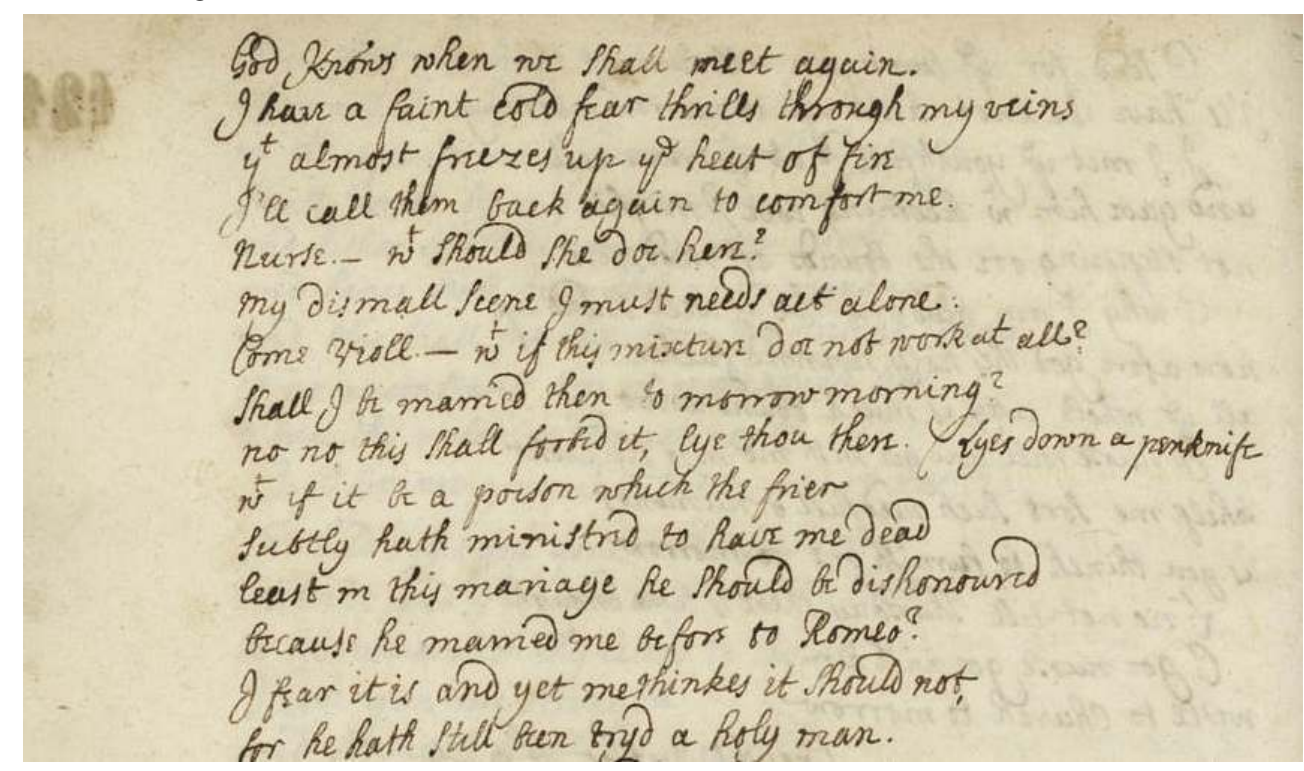

Fig. 1: Douai manuscript MS 787, fol. $121 \mathrm{v}$.

BY COURTESY OF THE BIBLIOTHÈQUE MUNICIPALE DE DOUAI.

While the choice of a penknife might sound rather prosaic in a tragedy, it is in fact quite apt: as a domestic object that anyone who had access to writing possessed, it could be owned by women as well as men, contrary perhaps to a dagger, which Juliet would have had to steal from a male relative (as she steals Romeo's dagger in the final scene). Pen- or quill-knives were used to sharpen quills (which required constant sharpening) and belonged to the writing-desk, which would have been kept in the drawing-room, the private closet - or, in the context of a college, the tutor's or student's cubicle. Pen-knives were not necessarily folding-knives, although some were, but they were essential accessories for a scribe, both to cut a feather into a quill pen and for erasing mistakes by scraping the surface of the paper. ${ }^{33}$ Although it is difficult to imagine Juliet killing herself with such a knife (and leaving the question of tragic decorum aside), this peculiar choice adds poignancy to the moment, it can be argued, by pointing to her fiery determination. As a writing instrument, it is also a symbol of how she authors herself as an agent of her own destiny, while it might also function as the discreet signature of the editor's own presence in the text.

A final type of intervention concerns textual changes and emendations. The editorreviser often modernizes the syntax (avoiding literary inversions, for instance), spelling and, to a certain extent, lexis. "Murther" is thus spelt "murder", "Alack" "Alas", "Ay" becomes "yes", and "county Paris" "Count Paris", for instance. He operates lexical substitutions, from the scale of single words to whole clauses. Some words substitutions, however, might seem quite gratuitous, as if reflecting personal preferences: in two instances, the editor-reviser substitutes the word "woeful" for "lamentable" (Douai manuscript, fol. 122v), "convey my service" for "convey my greetings" (fol. 117), or the word "designs" for "intents" (fol. 127v) - which might indicate a desire to ennoble the diction. Several substitutions aim at solving difficulties in the original, however, and constitute original emendations. In one instance, the editor corrects what he interprets 
as a compositorial error in F2: a segment which is repeated twice ("I will believe / Shall I beleeve, that unsubstantiall death is amorous?" [F2, fol. (iiiiv); 5.3.102-103]) - the Douai manuscript suggests: "Shall I beleeve that unsubstantiall Death / is amorous" (fol. 126v), an emendation which will only be introduced by Theobald in the eighteenth century. On numerous occasions, forty-seven according to G. Blakemore Evans, the manuscript supplies emendations which antedate historic emendations by eighteenth-century editors - from small changes of articles or tenses, to whole lines rephrased..$^{34}$ of particular interest, we can mention a correction introduced in 4.1.84-85: "Or bid me go into a new made grave / And hide me with a dead man in his grave." This was obviously an error of the compositor, whose eye got caught, and who inadvertently repeated the final word of the preceding line. The Douai editor substitutes the word "tomb" for "grave" (Douai manuscript, fol. 120), an original emendation which Malone also comes to almost a century later: it is the word "shroud" supplied by Q4 that is preferred by modern editors, however. ${ }^{35}$ Another original emendation occurs when Juliet tells Romeo "to cease [his] strife" if his intention is not marriage (2.2.152), which the Douai editor changes into "to cease [his] suit", a variant which features in Q4 only, and could have been reached independently. This emendation is not usually retained by modern editors - although it could be argued that "suit" actually reads better in the context and does not require a footnote, contrary to "strife". There are many emendations of a similar nature which indicate a sensitive and acute reader-cum-editor.

The Douai editor occasionally solves a difficulty simply by adding a stage direction. In a passage in which the nurse comes to find from Romeo what is to be done (in 2.4), the editor obviously thought the nurse's chattering too much and cut most of her speeches, adding the stage direction "they whisper" (2.4.134), possibly to make up for the fact that the dialogue, strangely enough, does not tell anything definite about Romeo's plans, or rather that the information seems to be given in the wrong order: although the first half of the dialogue ends with Romeo's comment, "Nurse, commend me to thy lady" (Douai manuscript, fol. 107v), and the nurse later adds, "this afternoon, sir? well she shall be there", nothing has yet been revealed about the said appointment. By adding the stage business "they whisper", the editor makes the spectator or reader assume that Romeo and the Nurse have already exchanged vital information, thus making the scene dramatically more efficient. ${ }^{36}$

To conclude, it seems likely that the Douai manuscript was used as a promptbook for amateur private performances - but perhaps a nuance should be introduced here between the uses (or functions) and the nature of a text: some of the plays transcribed here might have been used as a promptbook, but they are not just promptbooks. Although nothing more will probably emerge about the identity of its editor or first readers, the manuscript was indeed in all likelihood written within the Catholic community, as is obvious from the toning down of profanities and bawdy passages. A close examination of the manuscript reveals several layers of stage directions (at least three successive moments), which show that the text might have been used for a performance of some description at least on two different occasions after it was transcribed: some of the stage directions were obviously part of the initial copy; others, cramming the space around the text, seem to have been added at a later stage, perhaps on a second reading. Finally there is a third kind of stage direction in darker ink, obviously in a later hand (probably eighteenth-century), which indicates a later appropriation (fig. 2). 


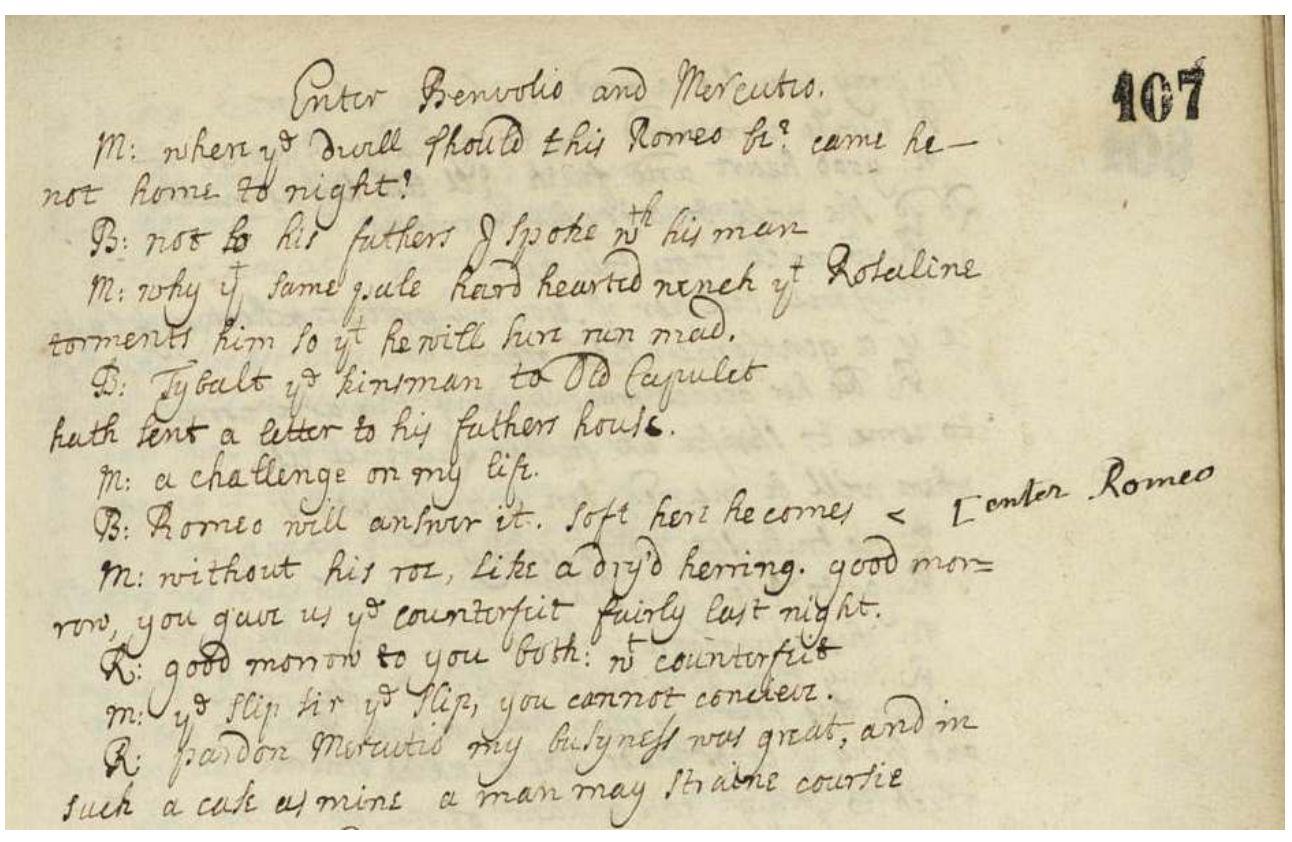

Fig. 2: Douai Manuscript MS 787, fol. 107r.

BY COURTESY OF THE BIBLIOTHĖQUE MUNICIPALE DE DOUAI.

("ENTER ROMEO" SEems to haVe BeEn ADded At A LATER StAge by A LATER haNd)

The volume, therefore, is probably a fair copy of play-texts used for some kind of performance among the English community - perhaps among the Douai residents, or their numerous visitors, rather than with the pupils themselves, given that the editor did nothing to censor female parts as was done in the annotated text of Henry IV, Part 2 in the Saint-Omer Folio, which was most certainly used for school exercises. ${ }^{37}$ Douai, as the most important centre for English recusants on the continent, housed a constant stream of visitors, including many English gentlemen on their way to or back from the SaintGermain Court, or on their Grand Tour. There would necessarily have been a social life of sorts to entertain those visitors. On what occasions were the plays read or performed? Although we have no records of public performances of such plays by students, they could have been used for amateur theatricals among older students, tutors, and visitors. In 1781, the English College introduced English literature (with arithmetic) into the curriculum, thirteen years before it was shut down (in 1794) and most of its library was sequestered by the revolutionary authorities. ${ }^{38}$ It is tempting to imagine that the manuscript might therefore have been used as a promptbook then, but this should not obscure the fact that it is also a creative edition in its own rights, obviously treasured by its owners for a century. 


\section{NOTES}

1. Bibliothèque municipale de Douai, MS 787. I am currently preparing a diplomatic edition of this manuscript, to be published with The Internet Shakespeare Editions, based at the University of Victoria (http://internetshakespeare.uvic.ca/, accessed 26 July 2018). I would like to thank Jean Vilbas, Curator of Rare Books at the Douai Library (Conservateur en charge des collections patrimoniales, Bibliothèque municipale de Douai), for his assistance and kindness.

2. The manuscript contains 323 leaves (probably numbered in the nineteenth century) and measures 22 by $17 \mathrm{~cm}$ (NB: it includes five unnumbered white pages and two pages with the same number).

3. On the history of the Douai Catholic institutions, see for instance Alexander Lock, Catholicism, Identity and Politics in the Age of Enlightenment: The Life and Career of Sir Thomas Gascoygne, 1745-1810, Woodbridge, Boydell Press, 2016, p. 41; David Lunn, The English Benedictines 1540-1688: From Reformation to Revolution, London, Barnes and Noble, 1980, p. 189; and Arthur Charles Frederick Beales, Education under Penalty: English Catholic Education from Reformation to Fall of James II, London, The Athlone Press, 1963, p. 178. On the English College in the eighteenth century, see P. R. Harris, “The English College, Douai, 1750-1794", Recusant History, 10.2 (1969), 79-95.

4. See in particular Maurice Whitehead, English Jesuit Education. Expulsion, Suppression, Survival and Restoration, 1762-1803, London, Ashgate, 2013.

5. See the special issue of Cahiers élisabethains around the rediscovery of the Saint-Omer Folio, Line Cottegnies and Jean-Christophe Mayer (ed.), "New Perspectives on Shakespeare's First Folio", Cahiers élisabéthains, 91.2 (March 2017), passim.

6. David Milburn, "Douai to Durham: the second centenary of Crook Hall", Northern Catholic History, 35 (1994), 18-37. For records of life in Douai, see The Douay College Diaries, ed. Edwin H. Burton and Thomas K. Williams, London, The Catholic Record Society, 1911, 5 volumes. See in particular vol. I, p. 238 and 270.

7. Crispu, tragoedia, Bibliothèque municipale de Douai, MS 772, Osvinus Seu Clementia tuta, Tragicomoedia, MS 789 (performed by the Class of Syntax at the Jesuit College of Douai on 3 June 1697). There is also a tragedy probably performed at the Jesuit College and entitled Habrahamus, trageodia (MS 771).

8. For a modern translation of the Ratio Studiorum, see Claude Pavur (ed.), The Ratio Studiorum: The Official Plan for Jesuit Education, Saint-Louis, The Institute of Jesuit Sources, 2005. My thanks to Maurice Whitehead, Schwarzenbach Research Fellow at the Venerable English College in Rome, and to Andrew Hiscock for conversations about the holdings of the English College.

9. Suzanne Gossett, “Drama in the English College, Rome, 1591-1660”, English Literary Renaissance, 3.1 (1973), 60-93, p. 61.

10. For the list of plays performed at the College for the period 1591-1660, see Gossett, "Drama in the English College, Rome, 1591-1660", op. cit., p. 91-93. I would like to thank Maurice Whitehead, currently Archive Coordinator at the Venerable English College in Rome, for his help in this matter.

11. G. Blakemore Evans, "The Douai Manuscript - Six Shakespearean Transcripts (1694-95)", Philological Quarterly, 41.1 (1962), 158-172.

12. Mr William Shakespeares Comedies, Histories, and Tragedies, London, Printed by Thomas Cotes for Robert Allot, 1632 (henceforth F2).

13. For the standard catalogue of Shakespearean promptbooks, see Charles H. Shattuck, The Shakespeare Promptbooks: A Descriptive Catalogue, Urbana and London, University of Illinois Press, 
1965. For a recent nuanced study of "promptbooks", see Paul Werstine, Early Modern Playhouse Manuscripts and the Editing of Shakespeare, Cambridge, Cambridge University Press, 2012, passim.

14. In J.-C. Mayer's felicitous phrasing, the Douai presents seventeenth-century readers that have "[e]scaped from the constraints of print by moving back to ms medium, which enabled them to give free rein to their creativity and shape Shakespeare's texts to their personal idea of how they should be performed" (Jean-Christophe Mayer, "Annotating and Transcribing for the Theatre: Shakespeare's early modern reader-revisers at work", in Margaret Jane Kidnie and Sonia Massai [ed.], Shakespeare and Textual Studies, Cambridge, Cambridge University Press, 2015, 163-176 , p. 171).

15. Arthur F. Marotti and Laura Estill, "Manuscript Circulation", in Arthur F. Kinney (ed.), The Oxford Handbook of Shakespeare, Oxford, Oxford University Press, 2012, 53-70, p. 64.

16. Ann-Mari Hedbäck, "The Douai Manuscript Reexamined", The Papers of the Bibliographical Society of America, 73.1 (1979), 1-18.

17. William Shakespeare, As You Like It, ed. Juliet Dusinberre, The Arden Shakespeare, Third Series, London, Bloomsbury, 2006; Twelfth Night, ed. Keir Elam, The Arden Shakespeare, Third Series, London, Bloomsbury, 2014; The Comedy of Errors, ed. Kent Cartwright, The Arden Shakespeare, Third Series, London, Bloomsbury, 2016; Romeo and Juliet, ed. René Weis, The Arden Shakespeare, Third Series, London, Bloomsbury, 2015; Macbeth, ed. Sandra Clark and Pamela Mason, The Arden Shakespeare, Third Series, London, Bloomsbury, 2015; Julius Caesar, ed. Tony Bradman, The Arden Shakespeare, Third Series, London, Bloomsbury, 2011; Romeo and Juliet, ed. G. Blakemore Evans, Cambridge, The New Cambridge, 2003 [1982]; Julius Caesar, ed. Marvin Spevack, Cambridge, The New Cambridge, 2004.

18. See for instance Marotti and Estill, op. cit., p. 64.

19. Don-John Dugas, Marketing the Bard - Shakespeare in Performance and Print, Columbia, University of Missouri Press, 2006, p. 67.

20. Ibid., p. 87. One counter-example is Julius Caesar, which is immensely popular, and yet mostly published in unaltered form.

21. Dusinberre, in As You Like It, Appendix 4, "The Douai Manuscript", op. cit., p. 374-387, in particular p. 376. Dusinberre wrongly attributes this scepticism to Hedbäck.

22. Jeffrey Todd Knight, "Shakespeare and the Collection: Reading beyond the reader's marks", in Kidnie and Massai (ed.), Shakespeare and Textual Studies, op. cit., 177-195.

23. Ibid., p. 178-179.

24. Ibid., p. 184.

25. Hedbäck, "The Douai Manuscript Reexamined", op. cit., p. 7-8.

26. Ibid., p. 2.

27. A Collection of the Best English Plays, The Hague and London, Printed for T. Johnson bookseller at the Hague, 1711-1712, 10 volumes.

28. For early literary anthologies which include extracts from Shakespeare's plays, see Roger Chartier and Peter Stallybrass, "Reading and Authorship: the Circulation of Shakespeare (1590-1619)", in Andrew Murphy (ed.), A Concise Companion to Shakespeare and the Text, Oxford, Blackwell's, 2007, p. 35-56. For a discussion of collections of quarto playbooks bound together, see T. S. N. Lennam, "Sir Edward Dering's Collection of Playbooks, 1619-1624", Shakespeare Quarterly, 16 (1965), 145-53.

29. Sonia Massai, "Early Readers", in Kinney (ed.), The Oxford Handbook of Shakespeare, op. cit., 143-162, p. 146.

30. Figures derived from Evans, “The Douai Manuscript”, op. cit., p. 167-172.

31. 1.1.90-92. Modern references to the play from the New Cambridge edition of Romeo and Juliet, op. cit.

32. "doing damned hate upon thyself" becomes "doing such an act upon thy selfe" in 3.3.118 (Douai, fol. 116). 
33. Pen-knives generally had narrow, short blades, curved on one side and straight on the other to make it easier to sharpen the pen. The handle, made of metal, horn, ivory, amber or other materials, could be more or less elaborate. See for example Pen-knife, XVIIIth century, $\mathrm{n}^{\circ}$ 1062-1902, Victoria \& Albert Museum, (http://collections.vam.ac.uk/item/O374453/penknifeunknown/, last accessed 30 April 2018).

34. Blakemore Evans, "The Douai Manuscript”, op. cit., p. 171.

35. Romeo and Juliet, ed. Blakemore Evans, op. cit., p. 160.

36. Inevitably, the Douai editor also unintentionally introduces new mistakes (ex: "noisome smells" instead of "loathsome smels", Douai, fol. 122).

37. See Line Cottegnies, "The Saint-Omer Folio in its Library", Cahiers élisabéthains, Special issue New Perspectives on Shakespeare's First Folio, op. cit., 13-32.

38. Harris, "The English College, Douai, 1750-1794", op. cit., p. 90.

\section{ABSTRACTS}

This essay looks at an exceptional manuscript collection of plays, dated 1694-1695 and held at the Bibliothèque municipale of Douai, which I am currently editing for The Internet Shakespeare Editions (http://internetshakespeare.uvic.ca/). It consists in a transcript of six plays by Shakespeare, bound together with three Restoration plays by Nathaniel Lee, John Dryden and William Davenant. The manuscript once belonged to one of the (Catholic) English colleges in Douai. As confirmed by the recently-discovered First Folio in Saint-Omer, English colleges abroad, including Jesuit colleges, had a rich theatrical culture, in which Shakespeare features in a prominent place. G. Blakemore Evans was the first scholar to highlight the importance of the Douai manuscript in 1962. He established that the scribe used the second Folio as copy-text for the Shakespeare plays and pointed out that the transcript contained multiple hithertounrecorded readings, which in some instances predate several of the best-known emendations by eighteenth-century scholars like Rowe, or Malone. This paper aims at reconsidering this collection as an anthology, in order to question the uses of the text and the reception of Shakespeare in a Catholic context. This necessarily means thinking about the status of this transcript by looking at the internal as well as external evidence: this essay argues that this collection, which has been interpreted as a promptbook by the critical tradition, i.e. a dramatic manuscript with a view to performance, should also be seen as an edition obeying Restoration editorial standards.

Cet article s'attache à un ensemble manuscrit exceptionnel de la Bibliothèque municipale de Douai, qui comprend six transcriptions de pièces de Shakespeare en anglais, datées de 1694-1695, reliées avec trois pièces de la Restauration, de Nathaniel Lee, John Dryden et William Davenant. L'auteur de cet article en prépare une édition diplomatique pour The Internet Shakespeare Editions ( http://internetshakespeare.uvic.ca/). C'est tout d'abord la provenance du manuscrit qui est exceptionnelle, puisqu'il a appartenu à l'un des collèges anglais (catholiques) de Douai. Comme l'a confirmé la redécouverte récente de l'in-folio de Saint-Omer, les collèges anglais sur le continent, notamment jésuites, eurent une riche culture théâtrale, où Shakespeare figure en bonne place. G. Blakemore Evans fut le premier à reconnaître l'importance de ce manuscrit dans un article important daté de 1962. Il établit en particulier que le copiste utilisait le second in-folio de Shakespeare (de 1632) comme texte de base pour ses transcriptions de Shakespeare et 
démontra que le manuscrit contenait de multiples émendations alors encore inédites et qui anticipaient dans de nombreux cas sur les corrections classiques des éditeurs philologues du XVIIIe siècle de Rowe à Malone. Cet article entend étudier le recueil en tant qu'anthologie, pour interroger les usages du texte (pour qui, pour quoi, par qui ?), ainsi que la réception de Shakespeare dans ce contexte universitaire et catholique si particulier. Pour ce faire, on tentera d'interpréter le faisceau d'indices internes aussi bien qu'externes. On tentera en particulier de montrer que le recueil, qui est communément vu par la tradition critique, suite à G. Blakemore Evans, comme un manuscrit dramatique préparatoire à une (ou plusieurs) mise(s) en scène, doit aussi être lu comme une édition de texte en bonne et due forme, bien qu'elle obéisse à des critères éditoriaux propres à la Restauration.

\section{INDEX}

Mots-clés: anthologie, Bibliothèque municipale de Douai, Catholiques anglais, Collège anglais de Douai, manuscrit dramatique, Récusants, Restauration anglaise, Shakespeare William, stratégies éditoriales, théâtre universitaire, Université de Douai

Keywords: academic drama, anthology, Bibliothèque municipale de Douai, Douai University, editorial strategies, English Catholics, English College in Douai, promptbooks, Recusants, Restoration, Shakespeare William

\section{AUTHOR}

\section{LINE COTTEGNIES}

Université Paris Sorbonne (EA 4085 VALE) 